\title{
Nadir bir alt gastrointestinal kanama nedeni: Rektal varisler
}

\author{
A rare cause of lower gastrointestinal bleeding: Rectal varices
}

Fehmi ATEŞ ${ }^{1}$, Bünyamin SARITAŞ ${ }^{1}$, Serkan YARAŞ ${ }^{1}$ Burcu BOZTEPE², Engin ALTINTAŞ ${ }^{1}$, Orhan SEZGIN ${ }^{1}$

Mersin Üniversitesi Tıp Fakültesi ${ }^{1}$ Gastroenteroloji Bilim Dalı, ${ }^{2}{ }^{\prime c ̧ ~ H a s t a l ı k l a r ı ~ A n a ~ B i l i m ~ D a l ı, ~ M e r s i n ~}$

Rektal varisler alt gastrointestinal sistem kanamasinin nadir bir sebebidir. Konjenital veya ailesel venöz anomaliler, portal hipertansiyon, kalp yetmezliği ve venöz trombozlar nedeniyle gelișebilir. Küçük bir bölümde ise sebep bilinmemektedir. Bu olgu; az görülmeleri nedeniyle tanı ve tedavisinde sıkça yanlışlıklara rastlanan rektal varislere dikkat çekmek için sunulmuştur.

Anahtar kelimeler: Alt gastrointestinal kanama, rektal varis

\section{GİRIŞ}

Rektal varisler alt gastrointestinal sistem (GIS) kanamasinın nadir bir sebebidir. Konjenital veya ailesel venöz anomaliler, portal hipertansiyon, kalp yetmezliği ve venöz trombozlar nedeniyle gelişebilir. Küçük bir bölümde ise sebep bilinmemektedir (1-2). Bu olgu; az görülmeleri nedeniyle tanı ve tedavisinde sıkça yanlışlıklara rastlanan rektal varislere dikkat çekmek için sunulmuştur.

\section{OLGU SUNUMU}

Otuzdört yaşındaki kadın hasta, yirmi yıldır zaman zaman olan ağrısız rektal kanama yakınmasıyla başvurdu. Hastanın daha önce aynı yakınmalarla genel cerrahi uzmanlarına başvurarak, hemoroid tanısıyla 4 kez opere edildiği öğrenildi. Rektal tussesinde koyu kırmızı renkte kanama bulgusu mevcuttu. Kolonoskopisinde rektumda dilate tortiyoze, üzerleri yer yer erozyone, vasküler oluşumlar izlenen hastanın diğer kolon segmentleri normaldi. Abdomen ultrasonografisinde (USG) ödemli rektum duvarı içinde portal akım örneği alınan damarsal yapilar izlendi. Karaciğer, dalak, hepatik venler, portal ven, safra yolları ve pankreas normaldi. Üst GIS endoskopisi normaldi. Endoanal USG'de, rektum duvarında submukozal kalınlaşma ve submukozal, perirektal çok sayıda genişlemiş, içinde venöz akım örneği alınan damarsal oluşumlar saptandı. Etiyolojiyi araştırmak için yapılan kardiyak değerlendirmelerde patoloji saptanmadi. Hemoglobin: 8,7g/dl, beyaz küre: 7040/mm³ trombosit: $298000 / \mathrm{mm}^{3}$ idi. Biyokimyasal testler, hemostaz ve hepatit belirteçleri normaldi. Trombofilik faktörlerden, Protein C, Protein S, Lupus antikoru, ANA, anti ds-DNA, C3, C4, kriyoglobulin, kriyofibrinojen, homosistein, Faktör VIII, Antitrombin III düzeyleri normal-
Rectal varices are a rare cause of lower gastrointestinal bleeding. Congenital or familial venous anomalies, portal hypertension, heart failure, and venous thrombosis are predisposing factors, and in a small proportion of patients, the etiology is unknown. This case is presented here in order to highlight the fact that rectal varices, which are rarely seen, can be misdiagnosed and mistreated.

Key words: Lower gastrointestinal bleeding, rectal varices

ken, Faktör V Leiden mutasyonu saptanmadı. Yalnızca heterozigot Protrombin-G20210 A mutasyonu belirlendi. Bilgisayarlı tomografi (BT) anjiografide, splenik ven, portal ven, superior mezenterik ven normalken, inferior mezenterik ven net görüntülenemedi. Perirektal alanlarda ve pelvik bölgede çok sayıda flebolitle uyumlu yuvarlak kalsifikasyonlar ve perirektal alanda genişlemiş variköz venler görüldü. Abdominal aorta, superior ve inferior mezenterik arter, bilateral renal arter kalibrasyonları normal olup solda aksesuar renal arter varyasyonu mevcuttu.

\section{TARTISQMA}

Rektal varisler alt GIS kanamasının nadir bir sebebidir. Rektal varislerin \% 75'inden fazlası portal hipertansiyona bağlıdır (1). Rektal varisin nedenleri, konjenital veya ailesel venöz anomaliler, portal hipertansiyon, kalp yetmezliği, splenik ven trombozu, süperior ve inferior mezenterik ven oklüzyonudur. Kü-

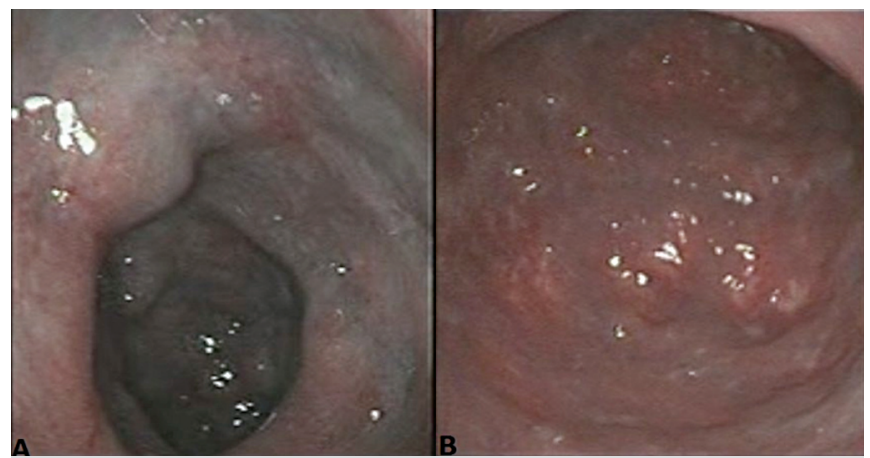

Şekil 1. Kolonoskopide dilate tortiyoze, üzerleri yer yer erozyone, vasküler oluşumlar saptandı. 


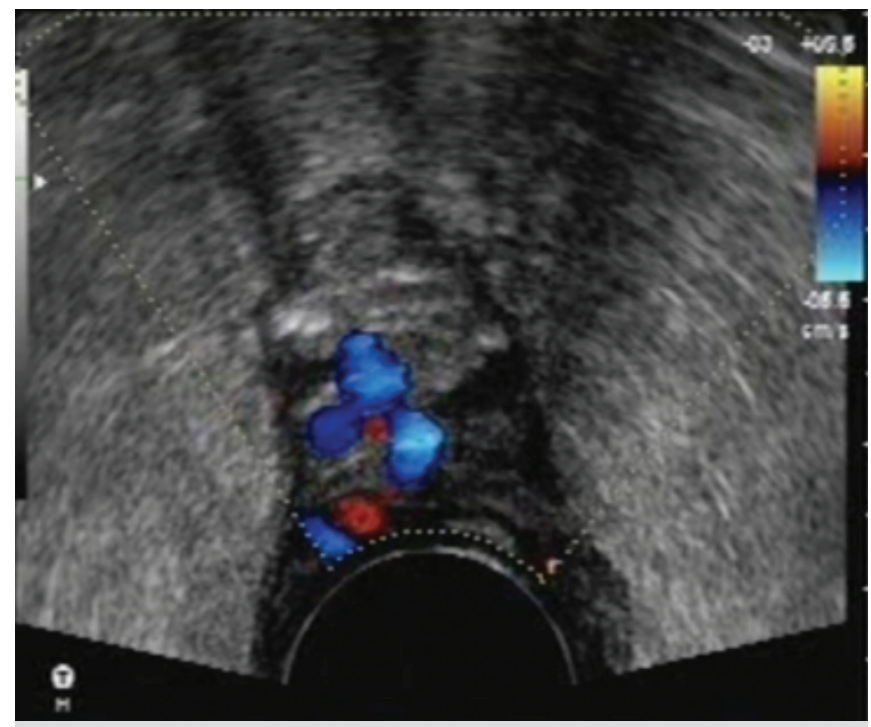

Şekil 2. Rektumdaki varislerin Doppler USG görüntüsü.

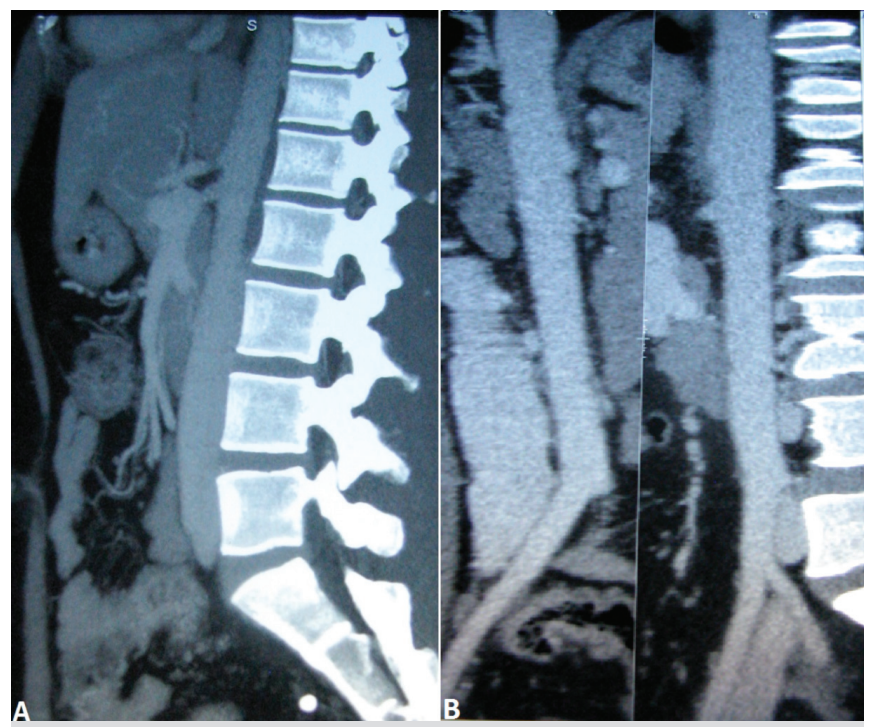

Şekil 3. BT anjiografide inferior mezenterik ven görüntülenemedi. çük bir bölümde ise sebep bilinmemektedir $(1,2)$. Kolonoskopide varisler tortiyoze, morumsu ve lümene prodrüde yapıdadır $(3,4)$. Polip, kanser ve ülseratif kolit ile nadiren karışabilmektedir. Yanlışlıkla biyopsi yapılması masif kanamaya neden olabilir (4). Kolon varisleri genellikle masif ve tekrarlayan ağrısız kanamayla birliktedir. Kanama distal kolondaki varislerin katı gaita nedeniyle yırtılması ya da mukozanın iskemik basınca bağlı yırtılması ile olur (5). İdiopatik rektal varislerin tanısı çoğunlukla mezenterik anjiyografi ile konulmaktadır. Mezenterik anjiografi ile tıkalı olan damar gösterilebilir ancak tıkanıklı̆̆ın venlerde olabileceği akılda tutulmalıdır.

Bizim vakamızda da ağrısız bir kanama vardı. Anjiyografik olarak sadece inferior mezenterik vende tromboz/oklüzyon

\section{KAYNAKLAR}

1. Feldman MSr, Smith VM, Warner CG. Varices of the colon. Report of three cases. JAMA 1962; 179: 729-30.

2. Weingart J, Hochter W, Ottenjann R. Varices of the entire colon-an unusual cause of recurrent intestinal bleeding. Endoscopy 1982; 14: 69-70.

3. Pickens CA, Tedesco FJ. Colonic varices. Unusual cause of rectal bleeding. Am J Gastroenterol 1980; 73: 73-4.

4. Vescia FG, Babb RR. Colonic varices: a rare, but important cause of gastrointestinal hemorrhage. J Clin Gastroenterol 1985; 7: 63-5. mevcuttu. Bu trombozun nedeni olarak hastada protrombin 2010 gen mutasyonu saptadik. Protrombin gen mutasyonu olan bireylerde venöz tromboz riski sağlıklı bireylere göre 3,8 kat artmıştır (6). Tedavi genelde konservatifdir.

\section{SONUÇ}

Çok uzun süredir tekrarlayıcı rektal kanaması olan bu hastada kolonoskopi ile saptanan rektal varisler, alt GIS kanamalarının etiyolojisinde rektal varislerin de düşünülmesi gerektiğini ve rektoskopik incelemenin bu nadir hastalığın tanısındaki değerini göstermektedir. Bununla birlikte altta yatan inferior mezenter ven trombozu gibi tıkanıklık saptanan hastalar, tromboza eğilim yaratan nedenler açısından dikkatle incelenmelidir.
5. Nikolopoulos N, Xynos E, Datsakis K, et al. Varicosis coli totalis: report of a case of idiopathic aetiology. Digestion 1990; 47: 232-5.

6. Emmerich J, Rosendaal FR, Cattaneo M, et al. Combined effect of factor V Leiden and prothrombin 20210A on the risk of venous thromboembolism--pooled analysis of 8 case-control studies including 2310 cases and 3204 controls. Study Group for Pooled-Analysis in Venous Thromboembolism. Thromb Haemost 2001; 86: 809-16. 